\title{
The effect of grape-skin extract on oxidative status
}

\author{
Jette F. Young ${ }^{1}$, Lars O. Dragsted ${ }^{2}$, Bahram Daneshvar ${ }^{2}$, Søren T. Lauridsen ${ }^{2}$, Max Hansen $^{2}$ and \\ Brittmarie Sandström ${ }^{1} *$ \\ ${ }^{1}$ Research Department of Human Nutrition, Royal Veterinary and Agricultural University, Frederiksberg, Denmark \\ ${ }^{2}$ Institute of Food Safety and Toxicology, Danish Veterinary and Food Administration, Søborg, Denmark
}

(Received 5 July 1999 - Revised 14 December 1999 - Accepted 8 February 2000)

\begin{abstract}
Epidemiological studies indicate that moderate alcohol consumption, particularly wine, reduce the risk of CHD. The present study was designed to investigate the effect of grape-skin extract on markers of oxidative status. The study was designed as a randomised crossover. A diet with a low content of flavonoids was served with strict control of intake in two consecutive 1-week intervention periods to fifteen subjects (nine women, six men) divided randomly into two groups. During one of the weeks the subjects from either group consumed $200 \mathrm{ml}$ grape-skin extract in water $(1 \mathrm{mg}$ extract $/ \mathrm{ml})$ at each of three daily meals $(31.3 \mathrm{mg}$ total phenolics, including $9.0 \mathrm{mg}$ catechin). An increased activity of glutathione reductase and a borderline increase of glutathione peroxidase activity in erythrocytes were observed after grape-skin intervention, while the intervention had no significant effect on superoxide dismutase or catalase. Likewise, no effect was found on 2-aminoadipic semialdehyde (AAS) residues, a plasma protein oxidation product, or on malondialdehyde in plasma or in LDL, which are markers of lipoprotein oxidation. A marginal effect of grape-skin intervention was observed on plasma ascorbate levels. Intake of the experimental diet significantly reduced plasma vitamin C and plasma AAS in both groups. This effect was most pronounced in the particular week with no grape-skin extract addition. We speculate that grape-skin extract may have a sparing effect on vitamin C. The effects of the experimental diet may be partly ascribed to a low content of several fruit- and vegetable-related antioxidants like flavonoids and vitamin $\mathrm{C}$ and a relatively high content of carrot-derived antioxidants, such as carotenes.
\end{abstract}

Grape-skin extract: Antioxidant status: Flavonoids

Epidemiological studies indicate that moderate alcohol consumption may reduce the risk of CHD (Klatsky \& Armstrong, 1993; Grønbæk et al. 1995). However, it is uncertain whether alcohol is the sole effective component or whether other components may contribute as well. Some epidemiological studies find red wine intake in particular to be associated with reduced risk of CHD (Renaud \& de Lorgeril, 1992; Grønbæk et al. 1995), but other results do not confirm this association (Klatsky \& Armstrong, 1993). In search of a mechanism for a potential protective effect, a number of human studies have investigated the effect of red wine consumption on antioxidant status in plasma (Fuhrman et al. 1995; Whitehead et al. 1995) as a surrogate marker for the aortic intima and in vitro susceptibility of LDL to oxidation (Kondo et al. 1994; Fuhrman et al. 1995; de Rijke et al. 1996). Studies comparing red wine with other alcohol-containing beverages showed reduced LDL oxidation only after red wine consumption (Kondo et al. 1994; Miyagi et al. 1997). Miyagi et al. (1997) did not observe any postprandial reduction in LDL susceptibility to oxidation after intake of red grape juice. However, following $7 \mathrm{~d}$ intervention with concentrated red grape juice, Day et al. (1997) found an increased serum antioxidant capacity as well as a reduced LDL oxidation, indicating that alcohol may not be the sole component responsible for this effect.

Antioxidative properties of red wine and/or grapes are believed to be due to the content of phenolic components. An inverse correlation between phenolic content and in vitro oxidation of LDL has been found (Frankel et al. 1995; Meyer et al. 1997). In comparison to red wine, white wine has a much lower antioxidant capacity (Whitehead et al. 1995 ) and is less protective towards LDL oxidation in vitro (Frankel et al. 1995) possibly because of the lower phenolic content (Hertog et al. 1993; Frankel et al. 1995). Fuhrman et al. (1995) studied the effect of red and white wine consumption and found a reduction in LDL oxidation after 2 weeks of red wine intake but a slight increase in LDL

\footnotetext{
Abbreviations: AAS, 2-aminoadipic semialdehyde; CAT, catalase; Gpx, glutathione peroxidase; GR, glutathione reductase; MDA, malondialdehyde; SOD, superoxide dismutase.

* Corresponding author: Professor Brittmarie Sandström, fax +45 352824 83, email bsa@kvl.dk
} 
oxidation after white wine consumption. However, de Rijke et al. (1996) did not find any effect of either red or white wine intake on LDL oxidation. If the antioxidative properties of red wine can be attributed to the phenolics in red wine and/or grapes, an extract of these compounds should demonstrate a similar effect. In vitro the effects of extracted phenolics from red wine showed an increase in the lag phase of LDL oxidation (Carbonneau et al. 1997). Intake of this extract caused an increase in total antioxidant capacity of plasma, whereas in vitro susceptibility to oxidation of LDL was not affected (Carbonneau et al. 1997).

In the present study we investigated the effect of grapeskin extract intake on markers of oxidative status in the blood. Fifteen subjects consumed grape-skin extract resulting in a daily phenolic intake corresponding to that of approximately $380 \mathrm{ml}$ red wine (de Rijke et al. 1996) for $7 \mathrm{~d}$ while keeping a strictly controlled experimental diet specifically designed to have a low content of flavonoids.

\section{Subjects and methods}

\section{Study design and diet}

The study design was a randomised crossover with a $2 \mathrm{~d}$ run-in period and two 1-week intervention periods in succession, as shown in Fig. 1. The experimental diet was composed of common foods selected to comply with a low content of flavonoids. The diet consisted of three menus consumed each week on days 1 and 4, 2, 5 and 7 and 3 and 6 respectively (Table 1 ). The subjects were divided into two groups. During one of the weeks the subjects from either group consumed $200 \mathrm{ml}$ grape-skin extract (for details see later) in water $(1 \mathrm{mg} / \mathrm{ml})$ at each of three daily meals, i.e. a total daily intake of $600 \mathrm{mg}$ grape-skin extract. The content of macronutrients and selected micronutrients in the diet was calculated using a computer program (Dankost; Danish Catering Center, Herlev, Denmark) which is based on the Danish Veterinary and Food Administration composition database (Møller, 1989) (Table 2). Each subject's energy requirement was estimated from body weight and degree of physical activity. All meals were prepared at the Research Department of Human Nutrition, Frederiksberg, Denmark, in individual portions
Table 1. Composition of experimental diet $(\mathrm{g} / \mathrm{d})$ at an energy intake of $10 \mathrm{MJ}$

\begin{tabular}{|c|c|c|c|c|}
\hline Meal & Component & Menu 1 & Menu 2 & Menu 3 \\
\hline Breakfast & $\begin{array}{l}\text { White bread roll with carrot } \\
\text { Butter } \\
\text { Cheese } \\
\text { Soured milk } \\
\text { Rye-bread crumb }\end{array}$ & $\begin{array}{r}78 \\
6 \\
30 \\
200 \\
30\end{array}$ & $\begin{array}{r}78 \\
6 \\
30 \\
200 \\
30\end{array}$ & $\begin{array}{r}78 \\
6 \\
30 \\
200 \\
30\end{array}$ \\
\hline Lunch & $\begin{array}{l}\text { Rye bread } \\
\text { Butter } \\
\text { Tuna salad } \\
\text { Ham } \\
\text { Egg salad } \\
\text { Turkey } \\
\text { Cottage cheese and ham } \\
\text { Roast beef } \\
\text { Carrot salad }\end{array}$ & $\begin{array}{r}100 \\
8 \\
50 \\
15\end{array}$ & $\begin{array}{r}100 \\
8\end{array}$ & $\begin{array}{r}60 \\
15 \\
155\end{array}$ \\
\hline Dinner & $\begin{array}{l}\text { Beef stew } \\
\text { Mashed potatoes } \\
\text { Cheese sauce } \\
\text { Pasta } \\
\text { Meat sauce } \\
\text { Rice }\end{array}$ & $\begin{array}{l}270 \\
257\end{array}$ & $\begin{array}{r}270 \\
70\end{array}$ & $\begin{array}{r}275 \\
70\end{array}$ \\
\hline Snack & $\begin{array}{l}\text { White bread roll with carrot } \\
\text { Cream cheese } \\
\text { Carrot cake } \\
\text { Sponge cake }\end{array}$ & $\begin{array}{r}117 \\
45 \\
51\end{array}$ & $\begin{array}{r}117 \\
45 \\
60\end{array}$ & $\begin{array}{r}117 \\
45 \\
51\end{array}$ \\
\hline Milk & & 250 & 250 & 250 \\
\hline
\end{tabular}

Table 2. Calculated macronutrient and selected micronutrient content of the diet/d per $10 \mathrm{MJ}^{*}$

\begin{tabular}{lc}
\hline Nutrient & Quantity \\
\hline Protein $(\mathrm{g})$ & $88 \dagger$ \\
Fat $(\mathrm{g})$ & $101 \ddagger$ \\
Carbohydrate $(\mathrm{g})$ & $252 \S$ \\
Vitamin A ( $\mathrm{g}$ retinol equivalents) & 2981 \\
Vitamin E (mg tocopherol equivalents) & $6 \cdot 0$ \\
Vitamin C (mg) & 23 \\
$\beta$-Carotene $(\mathrm{mg})$ & 17.4 \\
\hline
\end{tabular}

* Calculations were made using the computer program Dankost (Danish Catering Center, Kilnagleary, Carrigaline, Cork, Republic of Ireland) which is based on the Danish Veterinary and Food Administration composition database (Møller, 1989).

$\dagger 16 \%$ of energy.

$\neq 39 \%$ of energy.

$\S 45 \%$ of energy.

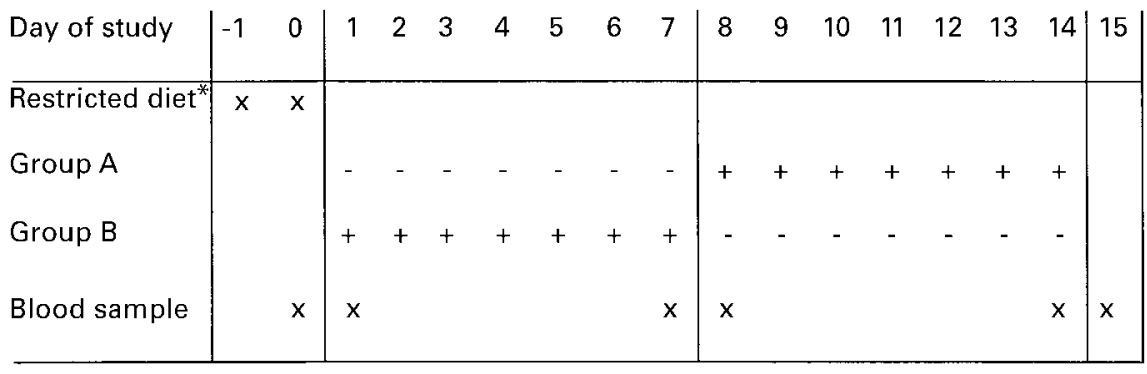

Fig. 1. Schematic illustration of the crossover design. *Instructions to omit all flavonoidcontaining food items for $2 \mathrm{~d}$ before intervention; (-), experimental diet with low-flavonoid content; (+), experimental diet with low-flavonoid content and $600 \mathrm{mg}$ grape-skin extract/d (Grape polyphenol powder P2157; Quest International, Kilnagleary, Carrigaline, Cork, Republic of Ireland). For details of experiment diet see Tables 1 and 2; for details of daily polyphenol intake see Table 3. 
according to energy requirement. One of the daily main meals was taken at the department while remaining (cold) meals were provided daily for intake at home. Subjects were instructed to return any leftovers to the department for weighing and subtraction from planned intake. Freeze-dried coffee powder was provided for preparation of coffee. Coffee intake varied between subjects but was held constant over the 2 weeks. No other foods and drinks than those provided from the department were allowed. Fasting blood samples were collected in the morning of day $0,1,7,8,14,15$, thus reflecting the preceding $24 \mathrm{~h}$, i.e. sample days 0 and 1 reflect baseline concentrations before intervention (day -1 and day 0 ) and the sample day 8 reflects the last $24 \mathrm{~h}$ of the first intervention week (day 7). The samples will be referred to in the text according to the $24 \mathrm{~h}$ they reflect. Body weight was determined before and after intervention to check weight stability. During the $2 \mathrm{~d}$ preceding the two 1-week intervention periods, the subjects were instructed to exclude flavonoid-containing foods from their diet: tea, wine, spices and all fruits and vegetables except potatoes were excluded from their diet.

\section{Grape-skin extract}

Grape polyphenol powder (P2157; Quest International, Kilnagleary, Carrigaline, Cork, Republic of Ireland) was an extract of black grapes (Vitis vinifera) standardised for colour strength and polyphenol content. The daily intake of some of the quantitatively most important compounds in the grape-skin extract is listed in Table 3. The polyphenol content was analysed on the same batch as used for the intervention by an independent certified laboratory on behalf of the manufacturer.

\section{Subjects}

Fifteen subjects (nine women, six men) volunteered for the study. The average age was 24 (range 21-33) years and average BMI was 22.3 (range $19 \cdot 1-24 \cdot 4) \mathrm{kg} / \mathrm{m}^{2}$. None of the subjects were pregnant, lactating, or had any chronic illness, and all were non-smokers. Subjects received oral and written information about the study, and gave their written consent. The subjects were initially interviewed to assess that their habitual diet was an ordinary varied Danish diet before run-in, and that they were taking no medicine or

Table 3. Daily polyphenol intake from $600 \mathrm{mg}$ grape polyphenol powder*

\begin{tabular}{lc}
\hline Compound & Daily intake $(\mathrm{mg})$ \\
\hline Total phenolics & 31.3 \\
Catechin & 9.0 \\
Caffeic acid & 1.6 \\
Epicatechin & 1.5 \\
Rutin & 1.5 \\
Quercetin & 1.2 \\
Myricetin & 1.8 \\
Resveratrol & 0.7 \\
Unidentified phenolics & 14.0 \\
\hline
\end{tabular}

* P2157; Quest International, Kilnagleary, Carrigaline, Cork, Republic of Ireland. Analysis was made on the same batch as used in the present study by an independent certified laboratory on behalf of the manufacturer. supplements. No dietary records were made. The study was approved by the local Research Ethics Committee of Copenhagen and Frederiksberg (Journal number KF01-092/ 96).

\section{Collection of blood samples and separation of erythrocytes and $L D L$}

Venous blood samples were taken in the morning after minimum $12 \mathrm{~h}$ fasting and supine resting for $10 \mathrm{~min}$. Subjects were instructed to avoid heavy physical activity for $36 \mathrm{~h}$ prior to blood sampling. Blood samples were collected in heparin-coated tubes and centrifuged at $1500 \mathrm{~g}$ for $10 \mathrm{~min}$ at room temperature. Plasma was stored at $-20^{\circ} \mathrm{C}$ until analysis (maximum 7 months). Erythrocytes were washed three times with three volumes $\mathrm{NaCl}(9 \mathrm{~g} / \mathrm{l})$, resuspended in one volume purified water for lysis, and then stored at $-80^{\circ} \mathrm{C}$ until analysis. Samples for ascorbate determination were kept on ice, centrifuged at $3000 \mathrm{~g}$ for $15 \mathrm{~min}$ at $4^{\circ} \mathrm{C}$ and the plasma was stabilised by addition of one volume metaphosphoric acid (100 g/l) before freezing at $-80^{\circ} \mathrm{C}$. LDL was isolated from plasma shortly after blood sampling by a single density gradient ultracentrifugation as described by Terpstra et al. (1981) using $1 \mathrm{ml} /$ plasma and analysed for malondialdehyde (MDA) immediately.

\section{Antioxidant enzymes}

Automated assays were performed on a Cobas Mira analyser (F. Hoffmann-La Roche Ltd, Basel, Switzerland) to determine the activity of the antioxidant enzymes superoxide dismutase (SOD), glutathione peroxidase (Gpx), glutathione reductase (GR) and catalase (CAT) in red blood cell lysates. SOD, Gpx and haemoglobin were determined using commercially available kits (SD125, RS505 and HG980 respectively; Randox, Ardmore, UK). GR activity and CAT activity were determined according to methods described by Wheeler et al. (1990). Glutathione, FAD, purpald and potassium periodate were purchased from Sigma Chemical Co. (St Louis, MO, USA). One red blood cell sample was selected as standard and analysed on twenty different days in order to obtain an established mean and standard deviation. This sample was also analysed in duplicate with each batch of analyses. The accepted interval for each of these determinations was the established mean \pm 2 sD for each of the four enzyme activities, otherwise the batch was reanalysed. Inter-day CV $(n 4)$ for this sample was found to be $7.6 \%$ (GR), $2.8 \%$ (Gpx), $6.3 \%$ (SOD) and $8.1 \%$ (CAT), whereas intra-day variation was below $3 \%$.

\section{Determination of malondialdehyde}

Total MDA was determined in plasma or LDL by a MDAHPLC method described previously (Lauridsen \& Mortensen, 1999). Briefly, the antioxidant butylated hydroxytoluene was added to the LDL samples to give a final concentration of $1 \mathrm{mmol} / \mathrm{l}$ and an alkaline hydrolysis was performed by adding $\mathrm{NaOH}$ (final concentration $0.5 \mathrm{~mol} / \mathrm{l}$ ) and heating for $30 \mathrm{~min}$ at $60^{\circ} \mathrm{C}$ to release any 
protein-bound MDA (Carbonneau et al. 1991). Samples were reacted with 2-thiobarbituric acid (Wallin et al. 1993) and after a centrifugation for $5 \mathrm{~min}$ at $10000 \mathrm{~g}$, the supernatants were analysed by HPLC: samples $(40 \mu \mathrm{l}$ aliquots) were analysed by chromatography using a linear gradient (0-50\%, 17 min) of $\mathrm{H}_{2} \mathrm{O}$-acetonitrile with $0.1 \%$ trifluoroacetic acid. The HPLC analysis was performed on a Hewlett-Packard 1100 system (Hewlett-Packard, Waldbromn, Germany) with diode array detector, using a Purospher RP-18 column $(4 \times 250 \mathrm{~mm}, 5 \mu \mathrm{m}$; HewlettPackard) and detection at $532 \mathrm{~nm}$. Four MDA standards were included in each 2-thiobarbituric acid reaction and HPLC-run. Sample peaks with retention times and u.v.spectra identical to the MDA-2-thiobarbituric acid standards were identified and the concentration of MDA was calculated from a standard curve and expressed as pmol MDA/mg protein. The intra-day $\mathrm{CV}$ for a standard was below $3.5 \%(n$ 4). MDA was purchased from Aldrich Chemical Co. (Steinheim, Germany), butylated hydroxytoluene, 2-thiobarbituric acid and NADPH were purchased from Sigma Chemical Co. Acetonitrile and methanol used were HPLC grade from Rathburne (Walkerburn, Lothian, UK).

\section{Determination of 2-aminoadipic semialdehyde in plasma proteins}

These procedures were performed as previously described by Daneshvar et al. (1997). Briefly, $1 \mathrm{mg}$ protein was dissolved in $0.25 \mathrm{~mol} N$-(morpholino)ethanesulfonic acid/l buffer $\mathrm{pH} 6.0$ containing $10 \mathrm{~g}$ sodium dodecyl sulfate/l and heated for $1 \mathrm{~min}$ at $100^{\circ} \mathrm{C}$. A solution of $0.25 \mathrm{~mol}$ fluoresceinamine $/ 1$ in $0.52 \mathrm{~mol} \mathrm{NaOH} / 1$ was added, followed by $0.25 \mathrm{~mol} \mathrm{NaCNBH}_{3} / 1$ in $0.25 \mathrm{~mol} N$-(morpholino)ethanesulfonic acid/l $\mathrm{pH} 6 \cdot 0$, and the mixture was incubated for $1 \mathrm{~h}$ at $37^{\circ} \mathrm{C}$. The mixture was applied onto a G-25 gel filtration column (Pharmacia, Uppsala, Sweden), and the column eluted with $N$-(morpholino)ethanesulfonic acid buffer. The protein fraction was collected and precipitated by addition of TCA. The precipitate was hydrolysed in $6 \mathrm{~mol} \mathrm{HCl} / 1$ at $110^{\circ} \mathrm{C}$ for $24 \mathrm{~h}$, and an internal standard of acetaldehyde-fluoresceinamine adduct was added. The hydrolysate was filtered and injected into an HPLC with a Pyrospher RP-18 column $(4 \times 250 \mathrm{~mm}$, $5 \mu \mathrm{m}$; Hewlett-Packard) eluted by a linear gradient of $0-$ $50 \%$ acetonitrile in $2 \mathrm{mmol}$ formic acid/l, $\mathrm{pH} \mathrm{3.2.} \mathrm{The}$ eluate was monitored at $454 \mathrm{~nm}$, the absorption maximum of decarboxylated fluoresceinamine, and at $275 \mathrm{~nm}$ for determination of free L-tyrosine, a marker for the quantity of hydrolysed protein. The result was corrected for the efficiency of protein hydrolysis and for the recovery of internal standard. Each sample was analysed on two different days. The variation between the two determinations of 2-aminoadipic semialdehyde (AAS) in any plasma protein sample was not allowed to exceed $10 \%$, otherwise samples were reanalysed. Mean intra-day variation was below $4 \%$.

\section{Determination of plasma ascorbic acid}

The concentration of ascorbic acid in metaphosphoric acid-stabilised plasma was analysed before intervention (baseline) and after each week of intervention, with and without grape-skin extract respectively. The concentration of ascorbic acid in the diet was constant throughout the intervention periods (calculated ascorbic acid content of the diet/d per $10 \mathrm{MJ}$ is shown in Table 2) and thus independent of the intervention. Plasma ascorbic acid was determined by HPLC according to Kall \& Andersen (1999).

\section{Statistics}

Biomarker analyses were performed on duplicate blood samples (taken on two successive days) during run-in, after 1 week and after 2 weeks. The means of these duplicates were used in the statistical analyses. The effect of period and the presence of carry-over (period $\times$ effect interactions) were determined by $t$ tests according to Pocock (1998). Due to the risk of period effects when no wash-out period was used, the effects of intervention was determined for all biomarkers by the paired $t$ test as suggested by Pocock (1998) to reduce such effects. In the case of significant carry-over, intervention effects were determined by comparing groups $\mathrm{A}$ and $\mathrm{B}$ by $t$ test in the first period only. ANOVA (GLM procedure, SAS 6.12; Statistical Analysis Systems Institute Inc., Cary, NC, USA) with a repeated statement for the sampling days was used to test for intra-individual variation during the whole $15 \mathrm{~d}$ experimental period for each of the biomarkers. Further analyses of these variations were performed by comparing intra-individual differences in biomarker responses between sampling times by paired $t$ tests. Due to the many tests performed, a $P$ value $<0 \cdot 01$ was considered statistically significant.

\section{Results \\ Subjects}

The subjects were weight stable, i.e. body weight changes were less than $1 \mathrm{~kg}$, except in one individual who lost $1.3 \mathrm{~kg}$ over the 2 -week intervention period.

\section{Biomarkers of antioxidant status}

There were no significant differences in biomarkers between males and females or between the two groups in the run-in period but group A had somewhat lower levels of MDA in LDL than group B before run-in $(P=0.03)$. There was a significant period effect in the case of ascorbate $(P<$ $0 \cdot 001)$ and significant carry-over (period $\times$ effect interaction) in the case of GR $(P=0.001)$, whereas carry-over for Gpx was borderline $(P=0.04)$. The effects of the crossover intervention with and without grape-skin extract on the biomarkers for antioxidative status are shown in Table 4. None of the biomarkers MDA, AAS, CAT or SOD were significantly changed after grape-skin extract addition to the experimental diet. Plasma ascorbate showed a borderline increase during the grape-skin intervention after correction for period effects $(P=0.02)$. Due to carryover, the effects of GR and Gpx could only be assessed by comparing the two groups after the first week of 
Table 4. Concentration of malondialdehyde in LDL, plasma 2-aminoadipic semialdehyde residues and activities of superoxide dismutase, glutathione peroxidase, glutathione reductase and catalase in red blood cells after 1 week's intake of the experimental diet $\dagger$ with (+) and without (-) $600 \mathrm{mg}$ grape-skin extract/dł

(Mean values and $99 \% \mathrm{Cl}$ for fifteen subjects)

\begin{tabular}{|c|c|c|c|c|c|c|}
\hline \multirow[b]{2}{*}{ Biomarker } & \multicolumn{2}{|c|}{-Grape skin } & \multicolumn{2}{|c|}{ +Grape skin } & \multicolumn{2}{|c|}{ Paired difference } \\
\hline & Mean & $99 \% \mathrm{Cl}$ & Mean & $99 \% \mathrm{Cl}$ & Mean & $99 \% \mathrm{Cl}$ \\
\hline MDA in LDL (pmol/mg protein) & 706 & 595,818 & 712 & 593,831 & 5.9 & $-152,164$ \\
\hline MDA in plasma (pmol/mg protein) & 50.5 & $46 \cdot 3,54 \cdot 8$ & $53 \cdot 6$ & $47 \cdot 7,59 \cdot 4$ & $3 \cdot 0$ & $-3 \cdot 0,9 \cdot 0$ \\
\hline Plasma AAS (pmol/mg protein) & $18 \cdot 5$ & $16 \cdot 9,20 \cdot 1$ & $19 \cdot 0$ & $17 \cdot 4,20 \cdot 6$ & 0.47 & $-1.91,2.85$ \\
\hline Ascorbic acid $(\mu \mathrm{mol} / \mathrm{l})$ & $35 \cdot 7$ & $29 \cdot 2,42 \cdot 2$ & $38 \cdot 3$ & $33 \cdot 1,43.5$ & 2.5 & $-2.5,8.9$ \\
\hline RBC SOD (U/g Hb) & 1038 & 997,1079 & 1043 & 1001,1085 & 5.5 & $-31 \cdot 5,42 \cdot 6$ \\
\hline RBC Gpx (U/g Hb) & $43 \cdot 1$ & $37 \cdot 0,49 \cdot 2$ & $50 \cdot 0$ & $43 \cdot 8,56 \cdot 27$ & $6.9 \S$ & \\
\hline RBC GR (U/g Hb) & $6 \cdot 79$ & $6 \cdot 22,7.36$ & $8.09^{*}$ & $7.52,8.66$ & $1.30 \S$ & \\
\hline RBC CAT (U/g Hb) & $14 \cdot 0$ & $13 \cdot 0,15 \cdot 0$ & $13 \cdot 7$ & $12 \cdot 6,14 \cdot 8$ & -0.28 & $-0.75,0.20$ \\
\hline
\end{tabular}

MDA, malondialdehyde; AAS, 2-aminoadipic semialdehyde; RBC, red blood cell; SOD, superoxide dismutase; Hb, haemoglobin; Gpx, glutathione peroxidase; GR, glutathione reductase; CAT, catalase.

Mean value was significantly different from that of subjects without grape-skin intervention: ${ }^{\star} P<0.05$.

† For details of experimental diet see Tables 1 and 2.

‡ Grape polyphenol powder P2157; Quest International, Kilnagleary, Carrigaline, Cork, Republic of Ireland. For details of daily polyphenol intake see Table 3.

$\S$ Due to significant carry-over for GR and Gpx, the effect of intervention was tested in period 1 between the groups, and the differences are therefore not paired.

intervention. In period 1 there was a significant difference between the groups with respect to GR $(P=0 \cdot 001)$ and a borderline effect with respect to $\mathrm{Gpx}(P=0 \cdot 06)$.

A significant effect of the overall dietary change to the experimental diet was observed for AAS (decrease, $P<$ 0.0001 ) and ascorbate (decrease, $P<0.0001$ ) whereas it was borderline for MDA (increase, $P=0.03$ ) by repeated samples ANOVA (Table 5). In order to look further into the cause of these changes we analysed sequentially the changes from the run-in period to period 1 and from period 1 to period 2 in each group (Fig. 2). In group A, which had no grape-skin extract in period 1 we observed a significant decrease for AAS $(P<0.001)$ and ascorbate $(P=0.002)$ and a significant increase with respect to MDA in LDL $(P<0.01)$, confirming the observed overall effects. In group B we observed similar but weaker trends for AAS $(P=0.02)$ and ascorbate $(P=0.06)$. In the second period we observed no further significant changes in group A whereas in group B the further decline was significant for ascorbate $(P<0.01)$ and borderline for AAS $(P=0.05)$. The activities of red blood cell antioxidant enzymes SOD, GR and CAT did not change with the experimental diet as determined by repeated samples ANOVA, but Gpx increased non-significantly $(P=0 \cdot 07)$. Weak decreases in GR $(P=0.07)$ and CAT $(P=0.04)$ in group A from run-in to the end of period 1 as determined by paired $t$ tests were also observed.

\section{Discussion}

The effect of a grape-skin extract on biomarkers of oxidative status was studied in order to demonstrate any antioxidative in vivo characteristics of polyphenolic compounds in red wine. In order to facilitate a comparison between grape-skin extract and wine, the dose was selected to match realistic intakes of polyphenolics from red wine. The daily intake of grape-skin extract in this study corresponded to approximately $330 \mathrm{ml}$ red wine when based on catechin content and approximately $430 \mathrm{ml}$ wine when compared with the quercetin content of the wine used in an intervention study by de Rijke et al. (1996). In the present study the subjects were maintained on a lowflavonoid diet with strict control of intake in order to increase the possibility of detecting any effect of grape-skin

Table 5. Concentration of malondialdehyde in LDL, plasma 2-aminoadipic semialdehyde residues and activities of superoxide dismutase, glutathione peroxidase, glutathione reductase and catalase in red blood cells at baseline and after 1 and 2 weeks on the experimental diet $\dagger$ (Mean values and $99 \% \mathrm{Cl}$ in fifteen subjects)

\begin{tabular}{|c|c|c|c|c|c|c|}
\hline \multirow[b]{2}{*}{ Biomarker } & \multicolumn{2}{|c|}{ Baseline } & \multicolumn{2}{|c|}{1 week } & \multicolumn{2}{|c|}{2 weeks } \\
\hline & Mean & $99 \% \mathrm{Cl}$ & Mean & $99 \% \mathrm{Cl}$ & Mean & $99 \% \mathrm{Cl}$ \\
\hline MDA in LDL (pmol/mg protein) & 542 & 404,679 & 735 & 609,860 & 684 & 583,785 \\
\hline MDA in plasma (pmol/mg protein) & 51.8 & $47 \cdot 6,56 \cdot 1$ & 51.4 & $46 \cdot 4,56 \cdot 3$ & $52 \cdot 2$ & $47 \cdot 3,58 \cdot 1$ \\
\hline Plasma AAS (pmol/mg protein) & $24 \cdot 0$ & $21 \cdot 8,26 \cdot 2$ & $19 \cdot 8$ & $18 \cdot 2,21 \cdot 5$ & $17 \cdot 6^{*}$ & $16 \cdot 5,18 \cdot 7$ \\
\hline Ascorbic acid $(\mu \mathrm{mol} / \mathrm{l})$ & $59 \cdot 7$ & $48 \cdot 0,71 \cdot 4$ & $40 \cdot 7$ & $34.4,47 \cdot 0$ & $33.5^{*}$ & $29 \cdot 0,38 \cdot 0$ \\
\hline RBC SOD $(\mathrm{U} / \mathrm{g} \mathrm{Hb})$ & 1017 & 969,1065 & 1030 & 996,1063 & 1051 & 1004,1098 \\
\hline $\mathrm{RBC} \mathrm{Gpx}(\mathrm{U} / \mathrm{g} \mathrm{Hb})$ & 44.0 & $39 \cdot 2,48 \cdot 8$ & $46 \cdot 3$ & $41 \cdot 5,51 \cdot 2$ & $46 \cdot 8$ & $41 \cdot 9,51.6$ \\
\hline RBC GR (U/g Hb) & 7.45 & $6.92,7.98$ & $7 \cdot 39$ & $6.80,7.99$ & $7 \cdot 39$ & $6.83,7.95$ \\
\hline $\operatorname{RBC} \mathrm{CAT}(\mathrm{U} / \mathrm{g} \mathrm{Hb})$ & $14 \cdot 3$ & $12 \cdot 8,15 \cdot 7$ & $13 \cdot 8$ & $12 \cdot 8,14 \cdot 8$ & $12 \cdot 6$ & $12 \cdot 5,16 \cdot 1$ \\
\hline
\end{tabular}

MDA, malondialdehyde; AAS, 2-aminoadipic semialdehyde; RBC, red blood cell; SOD, superoxide dismutase; Hb, haemoglobin; Gpx, glutathione peroxidase; GR, glutathione reductase; CAT, catalase. 

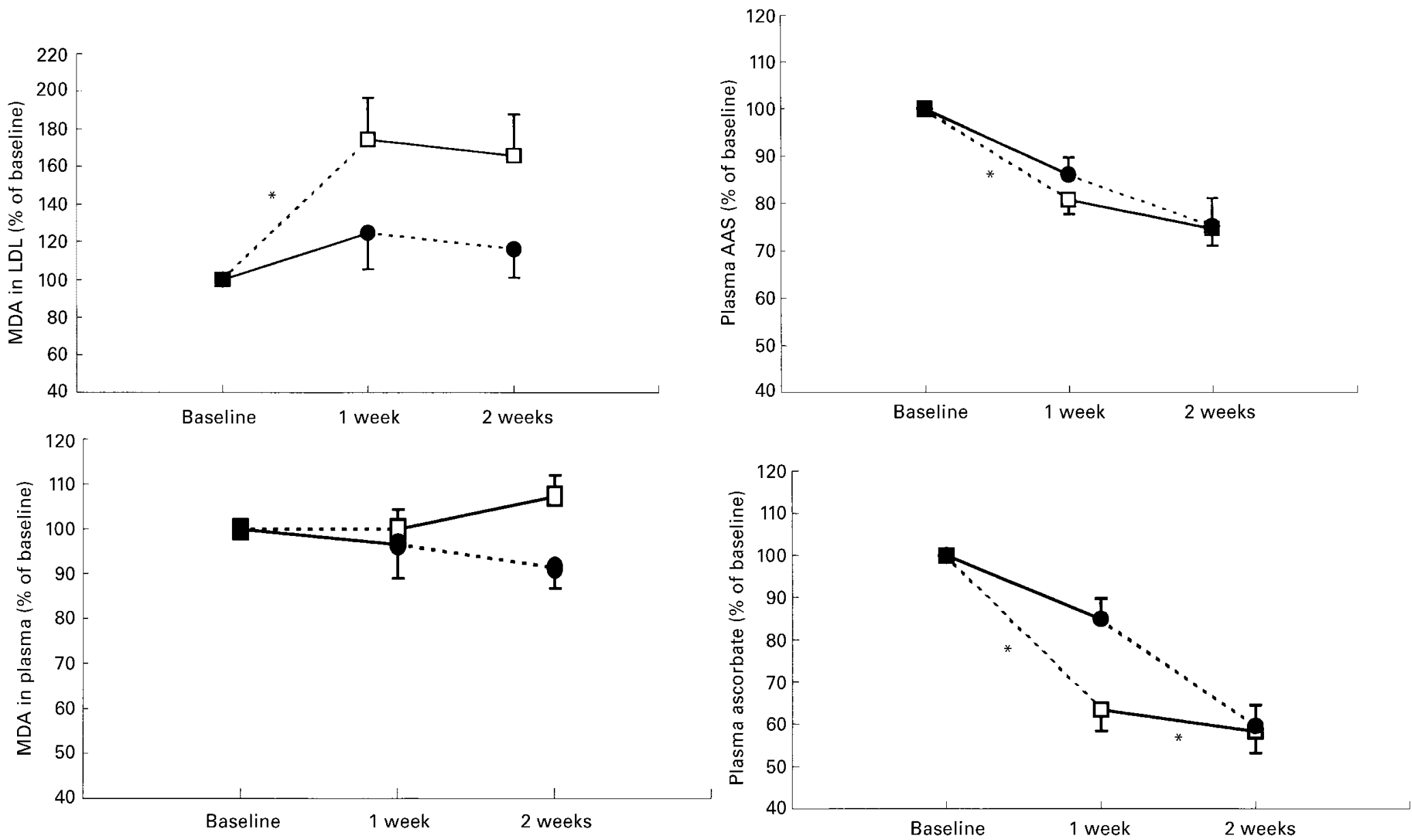

Fig. 2. Concentration of malondialdehyde (MDA) in LDL and plasma, plasma 2-aminoadipic semialdehyde (AAS) residues and plasma ascorbate at baseline and after 1 and 2 weeks on the experimental diet in eight subjects from group A ( $\square$ ) and seven subjects from group B $(\bullet)$ with (-) or without (----) $600 \mathrm{mg}$ grape-skin extract/d (Grape polyphenol powder P2157; Quest International, Kilnagleary, Carrigaline, Cork, Republic of Ireland). For details of experimental diet see Tables 1 and 2; for details of daily polyphenol intake see Table 3 . Values are means with standard errors of the means represented by vertical bars. Mean values were significantly different from values at previous time point: ${ }^{\star} P<0.05$. 
extract intervention. An increased activity of GR and borderline increases of Gpx activity in red blood cells and of plasma ascorbate concentrations were observed in the period of grape-skin intervention whereas other indices of oxidative status were not affected. It is unlikely that the small increase in Gpx during the total trial period was due to an improved Se status. The experimental diet did not contain any rich source of Se and a 2-week intervention period would not be sufficient to achieve major changes in red blood cell Gpx (Thomson et al. 1988). It has furthermore been demonstrated that ascorbic acid improves the bioavailability of Se (Mutanen \& Mykkänen, 1985) and thus if anything the Se status would be impaired as a consequence of the low ascorbic acid intake.

An intervention period of 1 week may seem inadequate for affecting red blood cell enzyme activities, but in previous studies we have observed an increase in Gpx activity after 1 week of apple-blackcurrant juice intake (Young et al. 1999), increased GR after 3 weeks of spinach intervention (Castenmiller et al. 1999) and increased GR and SOD after 1 week of parsley intake (Nielsen et al. 1999). In the present study, the Gpx and GR activities were higher in period 1 in group B who had grape-skin extract than in group A. Since group B had somewhat higher activity in these enzymes than group A throughout the trial periods, this may have been chance findings in the present study. Intake of grape-skin extract did not seem to affect plasma lipid oxidation.

We used a direct assay to assess LDL and plasma lipid oxidation in vivo by determining the actual concentration of the lipid oxidation product (MDA) in LDL and plasma by HPLC. The MDA and the $\mathrm{Cu}^{2+}$-induced lipoprotein oxidation lag time assays have been found to give inversely proportional results in experimental animals (S Lauridsen, A Mortensen, P Olsen, B Mayer and LO Dragsted, unpublished results). We observed a non-significant overall increase in the content of MDA in LDL during the 2-week trial due to a significant increase of MDA in LDL in group A during period 1 with no grape-skin (Fig. 2). We speculate that the grape-skin intervention in group B may have prevented this effect on MDA in LDL, and that the lack of a similar effect in period 2 might be explained by carry-over. For several other biomarkers, including ascorbate, AAS, CAT and GR we also observed a more marked change in group A than in group B during period 1 (Fig. 2). This might indicate an effect of the grape-skin extract on these markers in the opposite direction to that of the experimental diet. The dose of absorbed phenolics may have been too small or the intervention period too short to observe a significant protective effect of grape-skin intake on most of these biomarkers. Most likely, the strong effects of the experimental diet caused period effects and the lack of a wash-out period caused carry-over of any effects of the grape-skin extract due to our experimental design.

Other studies of 2-weeks duration have shown decreased in vitro oxidation of LDL in fasting blood samples, after ingestion of $400 \mathrm{ml}$ red wine/d with habitual diet (Fuhrman et al. 1995) and a similar effect was observed after ingestion of approximately $450 \mathrm{ml}(0.8 \mathrm{~g}$ ethanol $/ \mathrm{kg}) \mathrm{red}$ wine/d with a controlled diet low in phenolic substances (Kondo et al. 1994). In contrast, de Rijke et al. (1996) did not observe any effect on in vitro LDL oxidation after 4 weeks intake of $550 \mathrm{ml}$ red wine/d with a self-selected low-flavonoid diet. Thus, the background diet may have affected the different responses to wine and grape-skin extract. It is also possible that the processing of the grape skin including the removal of alcohol had changed the antioxidative properties of the phenolics or their bioavailability (Duthie et al. 1998).

As opposed to a possible increase in lipid oxidation with the experimental diet we observed a decrease in protein oxidation. In other studies we have observed a direct association between plasma ascorbate and AAS, indicating that ascorbate or other plant-derived antioxidants may be involved in Fenton-type oxidation of albumin (Castenmiller et al. 1999; Young et al. 1999; B Daneshwar, unpublished results). In the present study, the basic experimental diet was made to comply with a low-flavonoid intake. These compounds are predominantly present in fruits and vegetables, which are also the main sources of ascorbic acid. Decreases in plasma ascorbate can therefore be considered a marker of decreases in several non-grape-skin antioxidants resulting from the experimental diet. The experimental diet contained no fruits and only carrots as vegetables and had a calculated average ascorbic acid content of $23 \mathrm{mg} / \mathrm{d}$ per $10 \mathrm{MJ}$, which is approximately $25 \%$ of the average intake for this age-group in Denmark (91 mg/d per $10 \mathrm{MJ}$ ) (Haraldsdóttir et al. 1991). According to Biesalski et al. (1997) the optimal plasma concentration of ascorbic acid for preventing increased risk of $\mathrm{CHD}$ is $>50 \mu \mathrm{mol} / \mathrm{l}$. After 1 week of intervention the mean plasma ascorbic acid concentration was at $40.7 \mu \mathrm{mol} / \mathrm{l}$ decreasing further to $33.5 \mu \mathrm{mol} / 1$ after the second week of intervention. The decrease was only significant for group A during period 1 and for group B during period 2 (Fig. 2), i.e. in the periods when no grape skin was supplied. We speculate that this might be due to a weak sparing effect of grape-skin extract on vitamin $\mathrm{C}$.

Low plasma ascorbic acid may also specifically have led to the observed increase of MDA in LDL in group A in the first period of the present study (Fig. 2). Repletion of ascorbic acid in plasma from $13.5 \mu \mathrm{mol} / \mathrm{l}$ to $51.7 \mu \mathrm{mol} / \mathrm{l}$, by citrus fruit supplementation, significantly increased the lag time of in vitro LDL oxidation (Harats et al. 1998), indicating that ascorbic acid had a protective effect despite its absence from the LDL particles. The experimental diet had a relatively high calculated content of $\beta$-carotene (Table 2). Early in vitro studies of LDL oxidation suggested a possible role of $\beta$-carotene in delaying the onset of LDL oxidation (Esterbauer et al. 1989); in addition, a supplementation study using a $\beta$-carotene concentration ten times higher $(180 \mathrm{mg} / \mathrm{d})$ than that of the experimental diet in the present study showed a decrease in in vitro oxidation of LDL (Levy et al. 1996). However, other supplementation studies have not shown any consistent effect on the oxidative susceptibility of LDL particles (Tribble, 1999). Exogenous antioxidants such as flavonoids or other polyphenols have not been investigated as plasma antioxidants in a similar way, so their overall contribution cannot be compared. The decrease in ascorbate per se may also have resulted in the decreased AAS. However, other dietary factors co-existing with ascorbate 
are more likely to have caused such effects since ascorbate does not seem otherwise to have pro-oxidant effects in the blood (Frei et al. 1988). Alternatively, the experimental diet may have contained other antioxidants (e.g. carotenes, simple phenolic acids) capable of specifically protecting lysine residues in plasma proteins, thereby causing the observed decrease in AAS. However, recent results from a spinach intervention study does not support a role for $\beta$ carotene or lycopene in protection of lysine residues (Castenmiller et al. 1999).

In conclusion, with the exception of a small effect of GR activity, grape-skin extract in an amount corresponding to the phenolic content of $300-400 \mathrm{ml}$ red wine did not influence markers of antioxidative status. The experimental diet per se led to non-significantly increased MDA concentration in LDL, and to reduced plasma protein oxidation and reduced plasma ascorbate. This demonstrates that changes in markers of oxidative stress and of antioxidative defence can occur within normal variations in dietary intake of antioxidant-rich foods.

\section{Acknowledgements}

This study has been carried out with financial support from the Commission of the European Communities, Agriculture and Fisheries (FAIR) specific RTD program, CT 95-0158 'Natural Antioxidants in Foods'. It does not necessarily reflect its views and in no way anticipates the Commission's future policy in this area. The authors wish to thank the laboratory technicians Anni Schou, Vibeke Kegel, and Ella Jessen for excellent assistance and Carina Andersen and Morten Kall, Institute of Food Chemistry and Nutrition, Danish Veterinary and Food Administration, Copenhagen, Denmark for the plasma ascorbic acid analyses.

\section{References}

Biesalski HK, Böhles H, Esterbauer H, Fürst P, Gey F, Hundsdörfer G, Kasper H, Sies H \& Weisburger J (1997) Antioxidant vitamins in prevention. Clinical Nutrition 16, 151155.

Carbonneau M-A, Léger CL, Monnier L, Bonnet C, Michel F, Fouret G, Dedieu F \& Descomps B (1997) Supplementation with wine phenolic compounds increases the antioxidant capacity of plasma and vitamin $\mathrm{E}$ of low-density lipoprotein without changing the lipoprotein $\mathrm{Cu}^{2+}$-oxidizability: Possible explanation by phenolic location. European Journal of Clinical Nutrition 51, 682-690.

Carbonneau M-A, Peuchant E, Sess D, Canioni P \& Clerc M (1991) Free and bound malondialdehyde measured as thiobarbituric acid adduct by HPLC in serum and plasma. Clinical Chemistry 37, 1423-1429.

Castenmiller JJM, Lauridsen ST, Dragsted LO, van het Hof KH, Linssen JPH \& West CE (1999) Beta-carotene does not change markers of enzymatic and non-enzymatic antioxidant activity in human blood. Journal of Nutrition 129, 2162-2169.

Daneshvar B, Frandsen H, Autrup H \& Dragsted LO (1997) Gamma-glutamyl semialdehyde and 2-amino-adipic semialdehyde: biomarkers of oxidative damage to proteins. Biomarkers 2, 117-123.

Day AP, Kemp HJ, Bolton C, Hartog M \& Stansbie D (1997) Effect of concentrated red grape juice consumption on serum antioxidant capacity and low-density lipoprotein oxidation. Annals of Nutrition \& Metabolism 41, 353-357.

de Rijke YB, Demacker PNM, Assen NA, Sloots LM, Katan MB \& Stalenfoef AFH (1996) Red wine consumption does not affect oxidizability of low-density lipoproteins in volunteers. American Journal of Clinical Nutrition 63, 29-34.

Duthie GG, Pedersen MW, Gardner PT, Morrice PC, Jenkinson AM, McPhail DB \& Steele GM (1998) The effect of whiskey and wine consumption on total phenol content and antioxidant capacity of plasma from healthy volunteers. European Journal of Clinical Nutrition 52, 733-736.

Esterbauer H, Striegl G, Puhl J \& Rothender M (1989) Continuous monitoring of in vitro oxidation of human low density lipoprotein. Free Radical Research Communications 6, 67-75.

Frankel EN, Waterhouse AL \& Teissedre P-L (1995) Principal phenolic phytochemicals in selected California wines and their antioxidant activity in inhibiting oxidation of human lowdensity lipoproteins. Journal of Agricultural and Food Chemistry 43, 890-894.

Frei B, Stocker R \& Ames BN (1988) Antioxidant defenses and lipid peroxidation in human blood plasma. Proceedings of the National Academy of Sciences, USA 85, 9748-9752.

Fuhrman B, Lavy A \& Aviram M (1995) Consumption of red wine with meals reduces the susceptibility of human plasma and low-density lipoprotein to lipid peroxidation. American Journal of Clinical Nutrition 61, 549-554.

Grønbæk M, Deis A, Sørensen TIA, Becker U, Schnohr P \& Jensen G (1995) Mortality associated with moderate intakes of wine, beer, or spirits. British Medical Journal 310, 1165-1169.

Haraldsdóttir J, Holm L, Jensen JH \& Møller A (1991) Danskernes kostvaner 1985 1. Hovedresultater. Copenhagen: Danish Veterinary and Food Administration.

Harats D, Chevion S, Nahir M, Norman Y, Sagee O \& Berry EM (1998) Citrus fruit supplementation reduces lipoprotein oxidation in young men ingesting a diet high in saturated fat: presumptive evidence for an interaction between vitamins $\mathrm{C}$ and $\mathrm{E}$ in vivo. American Journal of Clinical Nutrition 67, 240245.

Hertog MGL, Hollman PCH \& van de Putte B (1993) Content of potentially anticarcinogenic flavonoids of tea infusions, wines, and fruit juices. Journal of Agricultural and Food Chemistry 41, 1242-1246.

Kall M \& Andersen C (1999) Improved method for simultaneous determination of ascorbic acid and dehydroascorbic acid, isoascorbic acid and dehydroisoascorbic acid in food and biological samples. Journal of Chromatography - Biomedical Applications 730, 101-111.

Klatsky AL \& Armstrong MA (1993) Alcoholic beverage choice and risk of coronary artery disease mortality: Do red wine drinkers fare best? American Journal of Cardiology 71, 467469.

Kondo K, Matsumoto A, Kurata H, Tanahashi H, Koda H, Amachi T \& Itakura H (1994) Inhibition of oxidation of low-density lipoprotein with red wine. Lancet 344, 1152.

Lauridsen ST \& Mortensen A (1999) Probucol selectively increases oxidation of atherogenic lipoproteins in cholesterolfed mice and in Watanabe heritable hyperlipidemic rabbits. Atherosclerosis 142, 169-178.

Levy Y, Kaplan M, Benamotz A \& Aviram M (1996) Effect of dietary supplementation of beta-carotene on human monocytemacrophage-mediated oxidation of low density lipoprotein. Israel Journal of Medical Sciences 32, 473-478.

Meyer AS, Yi O-S, Pearson DA, Waterhouse AL \& Frankel EN (1997) Inhibition of human low-density lipoprotein oxidation in relation to composition of phenolic antioxidants in grapes (Vitis vinifera). Journal of Agricultural and Food Chemistry 45, 1638-1643. 
Miyagi Y, Miwa K \& Inoue H (1997) Inhibition of human lowdensity lipoprotein oxidation by flavonids in red wine and grape juice. American Journal of Cardiology 80, 1627-1631.

Mutanen M \& Mykkänen HM (1985) Effect of ascorbic acid supplementation on selenium bioavailability in humans. Human Nutrition: Clinical Nutrition 39C, 221-226.

Møller A (1989) Food Composition Tables. Copenhagen: National Food Agency.

Nielsen SE, Young JF, Daneshvar B, Lauridsen ST, Knuthsen P, Sandström B \& Dragsted LO (1999) Effect of parsley (Petroselium crispum) intake on urinary apigenin excretion, blood antioxidant enzymes and biomarkers for oxidative stress in human subjects. British Journal of Nutrition 81, 447-455.

Pocock SJ (1998) Clinical trials. A Practical Approach. Chichester: Wiley \& Sons.

Renaud S \& de Lorgeril M (1992) Wine, alcohol, platelets, and the French paradox for coronary heart disease. Lancet 339, 1523 1526.

Terpstra AHM, Woodward CJH \& Sanchez-Muniz FJ (1981) Improved techniques for the separation of serum lipoproteins by density gradient ultracentrifugation: Visualization by prestaining and rapid separation of serum lipoproteins from small volumes of serum. Analytical Biochemistry 111, 149-157.

Thomson CD, Steven SM, van Rij AM, Wade CR \& Robinson MF
(1988) Selenium and vitamin E supplementation: activities of glutathione peroxidase in human tissues. American Journal of Clinical Nutrition 48, 316-323.

Tribble DL (1999) Antioxidant consumption and risk of coronary heart disease: Emphasis on vitamin $C$, vitamin $E$ and $\beta$ carotene. A statement for healthcare professionals from the American Heart Association. Circulation 99, 591-595.

Wallin B, Rosengren B, Shertzer HG \& Camejo G (1993) Lipoprotein oxidation and measurement of thiobarbituric acid reacting substances formation in a single microtiter plate: Its use for evaluation of antioxidants. Analytical Biochemistry 208, $10-15$.

Wheeler CR, Salzman JA, Elsayed NM, Omaye ST \& Korte DW Jr (1990) Automated assays for superoxide dismutase, catalase, glutathion peroxidase, and glutathion reductase. Analytical Biochemistry 184, 193-199.

Whitehead TP, Robinson D, Allaway S, Syms J \& Hale A (1995) Effect of red wine ingestion on the antioxidant capacity of serum. Clinical Chemistry 41, 32-35.

Young JF, Nielsen SE, Haraldsdóttir J, Daneshvar B, Lauridsen ST, Knuthsen P, Crozier A, Sandström B \& Dragsted LO (1999) Effect of fruit juice intake on urinary quercetin excretion and biomarkers of antioxidative status. American Journal of Clinical Nutrition 69, 87-94. 